\title{
Greiner's Model and Its Application in Automotive Companies in the Czech Republic
}

\author{
Lenka Sukova ${ }^{1}$
}

\begin{abstract}
This paper deals with Greiner's model, which is considered as an alternative concerning the life cycle of companies. There are many models that describe the life development of enterprises. The models differ in the number of individual phases, the size of the undertakings or their use. This paper aims to verify Greiner's model in the Czech Republic. The research was carried out in 2019 from September till the end of November and within the geographical delimitation of the Liberec region. The research included entrepreneurial subjects from the field of national economy - automotive industry. A characteristic of the companies in question is the effort to increase automation and robotization using various IT programs with the support of their IT department or external suppliers. In terms of their size, these were enterprises with a large number of employees (over 250). Due to the necessity of capturing their historical development, only enterprises established in the year 1999 or earlier were included in the research. The total database of surveyed enterprises contains 14 subjects, of which six enterprises participated in the research. The research was divided into two main parts. The first was a questionnaire survey carried out through an electronic link. This was followed by a controlled interview with selected representatives of the cooperating companies. The research has verified the assumption that the companies involved are at least in the third phase, i.e. in the delegation phase and above in Greiner's model. This was true about five out of the six companies. A benefit for the selected companies in relation to the identification of a specific phase of Greiner's model can be seen in the fact that the companies can anticipate the coming crisis, prepare for it and take appropriate measures. This enables to resolve the crisis relatively quickly and the company can move to the next stage - stage of evolution. The second assumption confirmed in four of the 6 subjects in the survey is that business units, regardless of the stage of Greiner's model, are targeting the three main features of the previous stages of revolution / evolution. These are the following: profitorientation, high work commitment of company employees and tasks and increasingly specialized assignments.
\end{abstract}

Keywords: Greiner's Model, Automotive Industry, Liberec Region, Czech Republic.

\section{Introduction}

Several theories concerning the life cycle of the business unit are described in the literature. During its existence, each business unit goes through several stages which to some extent affect its organizational structure, management and overall functioning. How is the life cycle of a business entity defined? What stages does the business go through?

\footnotetext{
${ }^{1}$ Faculty of Economics, Technical University of Liberec, Voroněžská 13, 46001 Liberec 1, Czech Republic

$\triangle$ lenka.sukova@tul.cz
} 
One of the possible theories that define the life cycle of a company is the theory so-called S-curve. (Dědina \& Malý, 2005; Wasserman, 2008) Another possible way of describing the development of a business entity is, for example, according to Synek et al. (2015). It divides the life of a company into five basic phases: establishment, growth, stabilization, crisis, and destruction. Yet another option, according to Adizes (2008), is to describe the life cycle of a business as a life of a live entity (an animal or a plant) i.e. from birth to death. These entities are born, they grow, reach old age and die.

Business literature is not uniform in relation to the number of phases of the life cycle of businesses. For example, the authors Smith, Mitchell and Summer (1985) talk about three basic stages of business development. In contrast, Baird and Meshoulam (1988), Quinn and Cameron (1983), as well as Kazanjian (1988), identify four phases of the development of a company. Greiner (1972), Miller and Friesen (1984), together with Scott and Bruce (1987), argue that businesses go through five stages of development.

There are other business growth models, which take into account not only the size of the companies but also their use in practise. The distribution is following. Industrial-growth models - use product life cycle to exemplify how industries develop and how the companies react to these pressures. Large business growth models - show characteristic changes in companies that have grown to a multi-dimensional unit that is geographically decentralized. Small Business Growth Models - developed models for small business units. (Scott \& Bruce, 1987) According to the definitions of the American Committee for Economic Development, the number of the employees defines small companies; it means 0-100 employees. General models of growth - these models include Greiner's model (1998), but also the models of Scott (1971) and Lippitt and Schmidt (1967). For these models, it is typical that they are applicable to businesses of various sizes and their versatility is guaranteed. (Scott \& Bruce, 1987)

An alternative life cycle theory is offered by Larry E. Greiner's theory, which was published in the article 'Evolution and Revolution as Organizations Grow' (Greiner, 1972, 1998) and which belongs to the universal models with a wide range of applications.

Greiner (1972) states that many companies are struggling with problems which are caused by past strategic management decisions rather than by current events or dynamic market developments. The management of the companies rushed the growth of their business and overlooked critical development issues, such as: Where is our company currently located? Where do we want to go? And what do these questions mean to our business in relation to business growth? Instead of answering these questions, the management focused on the external environment and the future.

Greiner has identified a series of development phases that businesses go through as they grow. Each phase begins with a period of evolution, then sustainable growth, stability and ends with a period of revolution with organizational turmoil and change. The decision made in each revolution period influences whether the business entity can move further forward, towards the next stage of developmental growth (Greiner, 1998).

The empirical research has helped to the development of the life cycle of the business units. Greiner analysed the research and discovered five key dimensions (Greiner, 1998):

- Age of the business entity,

- Size of the business entity,

- Phase of business development,

- Phase of business entity revolution,

- Growth of the selected sector. 
It is important to note that each phase has only one solution to the problem from the previous phase and at the same time, it contains the cause of the problem for the next phase. At each stage of business growth, managers are limited in how they can solve the problem. For example, a company experiencing a second-stage autonomy crisis cannot solve the problem by returning to directive-style management. On the contrary, the company must adopt a new management style - delegation - to move forward (Greiner, 1998).

The model includes the five phases, each of them (as described above) contains a problem and at the same time a solution (Greiner, 1972):

- first phase - creativity; crisis = professional management / leadership;

- $\quad$ second phase - professional management / leadership; crisis = autonomy;

- third phase - delegation; crisis = controls;

- fourth phase - coordination; crisis = bureaucracy;

- fifth phase - cooperation; crisis $=$ the future itself will show.

Companies in the fifth phase of business growth have not completely solved the crisis. Greiner believes that only time will show what they have a problem with. It will most likely be a problem of the organizational structure and programs that allow employees to rest regularly, recover and reflect on their work (Greiner, 1972). This article is mainly aimed at industrial enterprises and enterprises that produce consumer goods and does not apply to enterprises that provide services or knowledge.

Greiner (Berg \& Pietersma, 2015) in his next publication extended his model by the sixth phase. The fifth phase - cooperation, followed by the crisis, the internal growth of the company. This crisis is then followed by another period of growth of the company, which is called as an alliance.

Based on the above-mentioned literature review, Greiner's model is not, professionally and methodologically applied in the companies in the Liberec region in the Czech Republic. The author of this article found only a few bachelor's or master's theses dealing with this issue. The practical parts of these works are very poorly described methodologically and the empirical part contains only a statement about the stage in which the company is and the professional procedure with which the author reached this information is not further discussed. Only in one thesis (Odehnalová, 2011) was Greiner's model introduced, but it was in relation to family businesses of small and medium size and the construction industry.

The author of this article decided to verify the first assumption about the current phase of Greiner's model in selected business entities, geographically defined and based on other selected parameters. Assumption 1: The addressed and cooperating business entities are in the third or higher phase of Greiner's model, i.e. in the delegation phase or further.

Greiner's model also states that each phase of revolution and evolution has its characteristics. Neither foreign nor Czech literature describe whether some characteristics from the individual phases can be transferred to subsequent phases. Therefore, the author of the article decided to verify the following assumption 2: The features from previous phases of evolution/revolution (below) occur in at least four business entities, regardless of the stage of Greiner's model in which they are:

- profit-oriented,

- hard-working employees,

- increasingly specialized work tasks and assignments. 
The size of the enterprise also related to Greiner's model. The basic quantitative criteria for the assessment of the size of a company are the number of employees, annual turnover size, annual balance sheet (asset size) and independence. The data used to determine the number of employees and financial variables are those relating to the last tax year concluded, calculated for one calendar year. The size of enterprises according to the number of employees is defined as follows (CzechInvest, 2019):

- Large enterprises - more than 250 employees;

- Medium-sized enterprises -fewer than 250 employees;

- Small enterprises - fewer than 50 employees;

- Small entrepreneurs (micro-enterprises) -fewer than 10 employees.

\section{Methods}

In the first phase of the research, it was necessary to geographically define the area of investigation and then the business entities. Below are the individual selection parameters:

- Geographical demarcation of the surveyed area - Liberec region,

- National economy - manufacturing (automotive industry),

- Size of the companies - large companies (according to the number of employees, i.e. over 250),

- Founding year of the selected companies - 1999 or earlier.

Research area - Liberec region. In the framework of the empirical research, it was considered whether to focus on the whole Czech Republic or only on a selected region. The author of this article decided to observe and verify the established assumptions in relation to Greiner's model for a selected region, namely Liberec. The main reason for the selection of the above-mentioned region was primarily the knowledge of the local environment and of the individual business entities, including an already established cooperation within solved projects at the Department of Business Economics and Management.

National economy - manufacturing (automotive industry). The dominant industry in this region is the manufacturing industry (section C). It includes the automotive industry, followed by wholesale and retail trade, and repair and maintenance of motor vehicles (G). This is based on available data on the number of enterprises by CZ-NACE in 2018 and by the number of employees by CZ-NACE also in 2018 from the Czech Statistical Office. (Czech Statistical Office, 2019a, b) In addition, the automotive industry is one of the typical representatives of the industry in the Liberec region, which in this region has a long tradition and history. Based on this, the author of the article decided to carry out research in the automotive industry.

Another important part of Greiner's model is the growth rate of the target sector, in this case the automotive industry, which is part of the secondary sector, manufacturing, according to CZ-NACE Section C. (Czech Statistical Office, 2019c) The Automotive industry is very dynamic, fast and hectic, as indicated and reported by the following figures. Gross value added (at current prices) for 2017 clearly shows that industry contributed to the total national economy with $31.7 \%$, followed by trade with $11.1 \%$, construction with $5.3 \%$, agriculture with $2.3 \%$ and others with $49.6 \%$. (Czech Statistical Office, 2019d) The sectors of industry of the national economy can be analysed in detail concerning total gross value added in 2017. Manufacturing is in the first place with $84.6 \%$, followed by the energy sector with $9.8 \%$, then water supply with $3.3 \%$ and finally mining and quarrying with $2.3 \%$. (Czech Statistical Office, 2019d) Therefore, based on this information it is possible to classify the automotive industry sector as a very fast-growing industry sector. 
Size of the companies - the large companies were selected according to the criterion of the number of employees (i.e.: over than 250 employees). This criterion is important for capturing the history and development of companies. Moreover, it is based on the definition of the Small and Medium-sized enterprises according to the definition of European Union.

Established in 1999. Greiner's model maps the life cycle of a company, which made it necessary to select companies that have a long tradition in the market. The key year is the year of their foundation - it is 1999 or earlier. The companies that were part of this research are much older, their year of establishment ranges from 1992 to 1994.

Based on the above information, the following solution procedure has been established. The database of surveyed business entities was processed through the MagnusWeb portal. The author of the published article first tried to filter and process business entities through the ARES database (Administrative Register of Businesses). However, the disadvantage of this database is the fact that it is not possible to filter business entities according to the summary CZ-NACE, only by their subgroups. For this reason, the MagnusWeb database was used. It enables searching and filtering of enterprises according to CZ-NACE in total, i.e. including all its subgroups.

The selected companies were filtered by individual districts - Liberec, Semily, Jablonec nad Nisou and Česká Lípa - within the Liberec region. The resulting database includes 14 companies. Since the companies did not want to disclose their identification data, such as name, location of the organization, etc., these companies have been anonymized at their request.

The 14 companies mentioned above were approached with an offer of cooperation in the field of research. Unfortunately, 6 companies refused to cooperate after their management's consideration, 1 company promised to participate only in 1 of 2 research phases, 1 company refused to cooperate completely after the initial approval and face-to-face meeting and 1 company is still in the process of consideration. The research therefore uses six companies.

\section{Empirical research consisted of two parts:}

- The first part focused on the so-called "anchoring" of the company to the current phase of Greiner's model. A questionnaire was prepared for the companies and their "anchor", which consisted of three parts, and an electronic link was sent to the companies via email. The aim of the questionnaire was, inter alia, to verify the consistency of responses of the involved companies.

- The first part of the questionnaire focused on the characteristics of the various phases of the revolution and evolution of Greiner's model, which were grouped into several thematic areas, for example: communication, motivation and rewards, human resource management or finance. The task for the companies was to identify those features that were typical for them at the time.

- In the second part, the companies had a choice of nine thematic areas, which were in some way described and characterized in relation to Greiner's model. These thematic areas were compiled according to the individual phases of Greiner's model and its features of revolution and evolution, but without mentioning their names. This was so that the selected companies were not influenced by professional naming and were guided, if possible, by objective decisions. The task of the companies was to indicate the areas that the company went through and to determine the time range of individual phases, if possible. Another part of this task was a summary, i.e. an indication of the thematic area in which, according to the respondent(s), the company then was. Again, there were 9 thematic areas to choose from. 
- The third part was a follow-up to the previous and asked the respondents to fill in the characteristics of certain stages of Greiner's model according to the stage identified in the second part.

- The second part consisted of a structured interview with a selected representative (or employees) of the company. The chosen business representative had to meet two main conditions. First, it must have been someone who has been working in the company for a long time (preferably since the company's establishment), at least 6 years (sometimes two employees of the company were present at a controlled interview). Second: the employee had to be familiar not only with the production process (company products), but also with the administrative area and customers and suppliers. Based on the "anchorage of the company", questions for the interview were created and sent to the company in advance (Appendix D). The interviews in the companies were conducted after that. Each interview took from 60 minutes to 120 minutes, depending on the time and individual possibilities of the interviewed employee. The content of the controlled interview concerned the identified characteristics of the phases of Greiner's model selected by individual companies, how the individual features were reflected in the practical life of the company and how they manifested themselves in relation to the management of the company.

The questionnaire survey and the structured interview took place from September to November 2019. Table 1 below summarizes the information of the cooperating companies in relation to the structured interview. The first column (company name) identifies the individual companies under the working title A1 to F6. This is to keep them anonymous. The second column indicates the year in which the company was established. For some companies, there is another year given in brackets, indicating their existence before the revolution of 1989. The companies were then bought by another owner, but their business was preserved. The third column indicates the number of persons during the structured interview. The last column represents the job position of the persons who took part in the structured interview.

Table 1: Overview of information about the cooperating companies. Source: Author.

\begin{tabular}{|l|c|c|c|}
\hline $\begin{array}{c}\text { Name of } \\
\text { the } \\
\text { company }\end{array}$ & $\begin{array}{c}\text { Year of } \\
\text { foundation }\end{array}$ & $\begin{array}{c}\text { Number of persons } \\
\text { during the } \\
\text { structured } \\
\text { interview }\end{array}$ & $\begin{array}{c}\text { Job position of the } \\
\text { persons during the } \\
\text { structured } \\
\text { interview }\end{array}$ \\
\hline A1 & 1992 & 1 & CFO \\
\hline B2 & 1992 & 1 & HR manager \\
\hline C3 & 1994 & 1 & HR manager \\
\hline D4 & 1993 & 1 & $\begin{array}{c}\text { Supply chain } \\
\text { manager }\end{array}$ \\
\hline E5 & $(1946) 1991$ & 2 & $\begin{array}{c}\text { HR manager } \\
\text { Logistics manager }\end{array}$ \\
\hline F6 & $(1953) 1990$ & Participation only on questionnaire survey. \\
\hline
\end{tabular}


Company A1 has over 500 employees. Its field of the activity is the automotive industry. Nowadays the company uses automated processing of information on the business sector (especially in the human resources department, logistics and production) and solves automatization in the production. Company B2 has more than 1000 employees. Its field of activity is the automotive industry. Last year the company automated the flow of information in the shipping department. Company $\mathbf{C 3}$ has more than 500 employees. Its field of activity is the automotive industry and consumer market. The company invests in robotics and support IT systems in the production department. Company D4 has over 800 employees. Its field of activity is the automotive industry. Two years ago, this company implemented automated processing of information for the department of logistics and production. Company E5 has over 1000 employees. Its field of activity is the automotive industry. The company has automated processing of information in the production department and in human resources department and with the shipping department. The IT department supports this. Company F6 has over 750 employees. Its field of activity is the automotive industry. The production of this company is largely automated and supported by the IT department.

\section{Results}

This article presents the results of the verification of two assumptions based on professional literature review. The companies were very consistent in their answers during the structured interview. That is why the answers of the companies can be considered credible and truthful.

Assumption 1: The addressed and cooperating companies are in the third or higher phase of Greiner's model, i.e. in the delegation phase or further. The survey revealed that five of the six companies are at least in the third stage, i.e. in the stage of delegation within Greiner's model. This assumption has been confirmed. One company said that it is only in the second phase, i.e. at the stage of professional management/leadership. Two companies stated that they were in the third stage, i.e. in the phase of delegation. One company was in the fourth stage, i.e. at the stage of coordination. Two companies indicated that they were already in the fifth stage of Greiner's model, i.e. in the phase of cooperation. Table 2 below summarizes all the information obtained from the questionnaires.

Table 2: Summary of results in relation to the first assumption. Source: Author.

\begin{tabular}{|l|c|}
\hline Phase of Greiner's model & $\begin{array}{c}\text { Number of companies } \\
\text { in the stage of Greiner's } \\
\text { model }\end{array}$ \\
\hline First phase = creativity & 0 \\
\hline The crisis = professional management/leadership & 0 \\
\hline Second phase = professional management/leadership & 1 \\
\hline The crisis = autonomy & 0 \\
\hline Third phase = delegation & 2 \\
\hline The crisis = controls & 0 \\
\hline Fourth phase = coordination & 1 \\
\hline The crisis = bureaucracy & 0 \\
\hline Fifth phase = cooperation & 2 \\
\hline
\end{tabular}

Table 2 above shows that all companies are currently in an evolutionary phase, not a revolutionary phase. The benefit of identifying a company's phase in Greiner's model can be seen in the fact that companies can anticipate the upcoming crisis, prepare for it and respond 
appropriately. This makes it possible to resolve the crisis relatively quickly and get to the next stage, evolution, and subsequently a period of stability.

For example, the company under the working name E5 is currently in phase 3, i.e. the delegation phase. The selected company has certain characteristics at the given stage: a greater level of responsibility, which is allocated to managers of individual operations and market territories, the business is experiencing a period of growth and trying to expand into larger markets, the company created a profit centre and bonuses which motivate existing employees. However, the company knows that it is to expect a future period of crisis and crisis control. The given crisis, which has typical features, can be solved quickly, and prepared for well in advance in relation to the acquired knowledge of Greiner's model. In this way, other companies that participated in this research will be prepared.

Assumption 2: Characteristics of the previous stages of evolution/revolution (below) occur in at least four of the six companies, regardless of the stage Greiner's model in which they are.

- profit-oriented,

- hard-working employees,

- increasingly specialized work tasks and assignments.

Greiner (1972) states that the majority companies from Europe and the United States are already in the fifth phase of his model, i. e. in the cooperation phase. It was not in the article by Greiner more discussed and defined the word "majority", the author of this article decided to set the "majority" of companies like four out of 6 , which is about $70 \%$ according to the above assumption 2.

The survey showed that all three of these attributes appear in four of the six companies. This assumption can be confirmed.

In the case of the attribute 'profit-oriented', the companies even said in the structured interview that the orientation on profit is extremely high. Their Czech operation is under extreme pressure to make profits. Regardless of the stage of Greiner's model, it is to continue being one of the main objectives of the company and the goal closely monitored by management.

The attribute 'hard-working employees', as the companies indicated in the structured interviews, manifests itself in the form of overtime and continuous operation mode. For three companies, this is a high pace of work, both for technical and economic staff and shop floor employees. One company said that it is only concerned with salaries. Based on the structured interview, the cause can be seen primarily in increasing production volumes, increasing productivity, managing a central operation from abroad (meeting global operation objectives), buying new equipment/building new production lines, competitive pressure and in an effort to reduce labour costs.

As for the attribute 'increasingly specialized work tasks and assignments' the structured interviews showed that more tasks appear which are specialized, both for technical and economic staff and shop floor employees. According to the cooperating companies, this is mainly due to the increasingly specific wishes and requirements of the customers, the emerging robotics and automation.

\section{Discussion and conclusion}

Greiner's model and its application for the companies conceal many other scientific questions, for example whether companies always have to go through all these phases in their development 
or whether they can be skipped. An example of the practical application of Greiner's model to the American company Kodak (dealing with the production of cameras and camera accessories) proves that this company went through all phases individually, from the creativity phase to the collaboration phase. (Mimbang \& Feys, 2016) However, some companies may be "satisfied" at the stage where they are and do not tend to change anything. This idea is confirmed and documented by research on family businesses in Czech environment. (Odehnalová, 2011) How long do the individual phases of Greiner's model last in Czech environment and in certain fields of the national economy (for example the automotive industry)? What organizational structure do companies have and do they change it in a fundamental way during their development according to Greiner's model? Currently, to the above questions there are not any answers from the scientific research and literature in relation to the Czech area.

Given that Greiner's model has not yet been applied in the Czech Republic, it offers great opportunities for further empirical research. It is possible to find bachelor's and master's theses that deal with this issue. However, their conclusions are based only on a brief statement without accompanying commentary regarding the methodology. It is also possible to find one dissertation thesis (Odehnalová, 2011) which dealt with this issue. However, the research was focused on construction and family businesses. Based on her further empirical research, the author of the article would like to answer the above questions in her further publishing activities. In future, the author of this article would also like to apply this model to other companies, for example in the glass industry in the Liberec region, since the automotive industry together with the glass (jewellery) industry are typical industries of the studied region.

The present article dealt with one of the many known models, namely Greiner's model, and empirical research in the geographically defined area NUTS II Northeast - Liberec region, Czech Republic. The research included companies that were selected on the basis of the following parameters:

- National economy - manufacturing (automotive industry);

- Size of the companies - large companies (based on the number of employees as defined by CzechInvest, i.e. over 250 employees);

- Growth rate of the selected sector - a fast-growing sector of the national economy;

- Founding year of the selected companies - 1999 or earlier. The companies that were part of this research were established between 1992 and 1994. It follows that the automotive industry has been operating in the Czech Republic for at least 25 years.

Six companies from the 14 respondents participated in the research. The database of the cooperating companies was processed through the MagnusWeb portal and based on the knowledge of the local environment. The Empirical research consisted of two parts: a questionnaire survey and structured interviews (with pre-prepared questions) with representatives of the companies involved. The two assumptions based on the literature review were verified. All information of the companies is anonymous according to the wishes of the representatives of the companies. Data collection took place from late September to November 2019.

The first stated assumption: The cooperating companies are in the third or higher phase of Greiner's model, i.e. in the delegation phase or further. This assumption was confirmed in the questionnaire survey and subsequently in the structured interviews.

This assumption was confirmed by five companies from the six cooperating companies. Only one company reported being in phase 2 of Greiner's model, i.e. in the professional management/leadership phase. This result is certainly largely supported not only by its long 
tradition of operating in the market (established in 1992-1994) but also by the industry in which the companies operate, the automotive industry. This industry is considered one of the fast growing and a typical representative of industry in the Liberec region.

The second stated assumption: Characteristics of the previous phases of evolution/revolution (below) occur in at least four companies, regardless of the stage Greiner's model in which the businesses are:

- profit-oriented,

- hard-working employees,

- increasingly specialized work tasks and assignments.

The questionnaire survey and subsequent structured interviews confirmed the above-mentioned features in four out of six companies.

In the attribute 'profit-oriented', the addressed companies stated that this pressure is currently extreme. Individual representatives of companies agree that no matter in what stage of Greiner's model the company is, profit was always the primary goal.

For the attribute 'hard-working employees', the addressed companies reported that the most common causes are the increasing production volumes, productivity improvements, purchase of new technologies/machinery/construction of new production lines and the pressure of competition.

In the attribute 'increasingly specialized work tasks and assignments' the reason is, according to the addressed companies, mainly the more specific wishes and requirements of customers and the upcoming robots with automation.

\section{Acknowledgements}

This article was supported by research project SGS-EF-3300-21299 “Životní cyklus podniků ve vazbě na vybrané aspekty" (The life cycle of the companies in relation to selected aspects), Faculty of Economics, Technical University of Liberec.

\section{References}

Adizes, I. (2008). The Adizes Lifecycle Assessment Survey. Adizes Institute. http://www.adizes.com/ lifecycle assessment form.html

Baird, L. \& Meshoulam, I. (1988). Managing Two Fits of Strategic Human Resource Management. The Academy of Management Review, 13(1), 116-128. https://doi.org/10.2307/258359

Berg, G., \& Pietersma, P. (2015). Key Management Models. Edinburgh Gate.

Czechlnvest. (2019). Definice malého a středního podnikatele. https://www.czechinvest.org/cz/Sluzby-pro-malea-stredni-podnikatele/Chcete-dotace/OPPI/Radce/Definice-maleho-a-stredniho-podnikatele

Czech Statistical Office. (2019a). Statistická ročenka Libereckého kraje 2019 - Trh práce. Zaměstnaní v národním hospodářství podle sekcí CZ-NACE v Libereckém kraji 2016-2018. https://www.czso.cz/csu/czso/9-trh-prace-4cc5wrc0of, 2012-2019

Czech Statistical Office. (2019b). Statistická ročenka Libereckého kraje 2019 - Organizační statistika. Ekonomické subjekty podle vybrané převažující činnosti. https://www.czso.cz/csu/czso/10-organizacnistatistika-wop40115qk

Czech Statistical Office. (2019c). Klasifikace ekonomických činností (CZ-NACE). https://www.czso.cz/documents/10180/20565267/021608.pdf/2f45895b-4c51-435b-a52a$\underline{0 \mathrm{c} 7164 \mathrm{dbf371} \text { ?version }=1.0}$

Czech Statistical Office. (2019d). Prümysl v České republice - tisková konference. https://www.czso.cz/csu/czso/prumysl-dosahl-historickych-objemu-a-zvolnil 
Dědina, J., \& Malý, M. (2005). Moderní organizační architektura. Alfa Publishing.

Greiner, L. E. (1972). Evolution and Revolution as Organizations Grow. Harvard Business Review, 50(4), 37-46.

Greiner, L. E. (1998). Evolution and Revolution as Organizations Grow. Harvard Business Review, 76(3), 55-68.

Kazanjian, R. K. (1988). Relation of Dominant Problems to Stages of Growth in Technology-Based New Ventures. The Academy of Management Journal, 31(2), 257-279. https://doi.org/10.2307/256548

Lippitt, G. L. \& Schmidt, W. H. (1967). Crisis in developing organizations. Harvard Business Review, 45(6), 102-112.

Miller, D., \& Friesen, P. H. (1984). A Longitudinal Study of the Corporate Life cycle. Management Science, 30(10), 1161-1183. https://doi.org/10.1287/mnsc.30.10.1161

Mimbang, B. J. \& Feys, B. (2016). The Greiner growth model - Anticipate crises and adapt to a changing business world. Amazon.

Odehnalová, P. (2011). Přednosti a meze rodinného podnikání. Masarykova univerzita.

Quinn, R. E., \& Cameron, K. (1983). Organizational Life Cycle and Shifting Criteria of Effectiveness: Some Preliminary Evidence. Management Science, 29(1), 33-51. https://doi.org/10.1287/mnsc.29.1.33

Scott, M., \& Bruce, R. (1987). Five Stages of Growth in Small Business. Long Range Planning, 20(3). 45-52. https://doi.org/10.1016/0024-6301(87)90071-9

Smith, K. G., Mitchell, T. R., \& Summer, C. E. (1985). Top Level Management Priorities in Different Stages of the Organizational Life Cycle. Academy of Management Journal, 28(4), 799-820. https://doi.org/10.2307/256238

Synek, M., Kislingerová, E. et al. (2015). Podniková ekonomika. C. H. Beck.

Wasserman, N. (2008). Revisiting the Strategy, Structure, and Performance Paradigm: The Case of Venture Capital. Organizational Science, 19(2), 241-259. https://doi.org/10.1287/orsc. 1070.0309

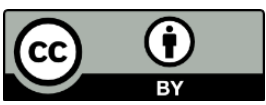

Copyright () 2020 by the author(s). Licensee University of Economics, Prague, Czech Republic. This article is an open access article distributed under the terms and conditions of the Creative Commons Attribution License (CC BY), which permits use, distribution and reproduction in any medium, provided the original publication is properly cited, see http://creativecommons.org/licenses/by/4.0/. No use, distribution or reproduction is permitted which does not comply with these terms.

The article has been reviewed. I Received: 20 January 2020 | Accepted: 20 May 2020

Academic Editor: Stanislava Mildeova 
